\title{
ANALISA PENGARUH FAKTOR PENDIDIKAN TERHADAP PARTISIPASI POLITIK PEREMPUAN PADA PEMILIHAN KEPALA DESA (PILWU) TAHUN 2017 DI KECAMATAN WIDASARI
}

\section{Nunung Nurjanah Syukron Ma'mun}

STKIP Pangeran Dharma Kusuma Indramayu JL. Ketapang, Segeran Kidul, Jatinyuat, Kabupaten Indramayu, Jawa Barat 45282

Email: nunungnurjanah22@gmail.com \& young_gun@gmail.com

\begin{tabular}{|c|c|c|}
\hline Diterima: & Revisi: & Disetujui: \\
23 Agustus 2018 & 08 Oktober 2018 & 19 November 2018 \\
\hline
\end{tabular}

\begin{abstract}
Background of this reaserch is the low of women participation in various agenda of general election in level national, province, or local. This reaserch amin to know the influence of level of education to woman political participation in election of Village head 2017 in Widasari District. The research approch in this reaserch is qualitatif approach with case study methode. Subyect in this reserah is woman candidats from three villages in Widasari District which perform the election of village head. From four villages which perform village head election, there is three villages with woman candidat of village head which is Kongsijaya Village, ujung jaya Village, and Leuwigede Village. The reaserch instrumen use in this reaserch is observation sheet and interview sheet to woman candidat of village head. The result of this reaserch is proof that education is not main determinant of women participation to nominate as village head. There is other factor that influence women participation in village head election in Widasari distric 2017 which is husband support and experience un social organization.
\end{abstract}

Keyword: education, woman, participation, and village head election

\begin{abstract}
Abstrak
Latar beakang penelitian ini yaitu rendahnya partisipasi politik perempuan dalam berbagai agenda pemilihan umum baik pada tingkat nasional, provinsi, maupun lokal. Penelitian ini bertujuan untuk mengetahui pengaruh faktor pendidikan terhadap partisipasi politik perempuan pada pemilihan kepala
\end{abstract}


desa tahun 2017 di Kecamatan Widasari. Pendekatan penelitian yang digunakan dalam penelitian ini adalah pendekatan kualitatif dengan metode penelitian studi kasus. Subyek dalam penelitian ini yaitu kandidat perempuan dari tiga desa di Kecamatan Widasari yang menyelenggarakan pemilihan kepala desa, dari empat desa yang menyelengagrakan pemilihan kepala desa di Kecamatan Widasari, tiga desa yang memiliki calon kepala desa perempuan yaitu Desa Kongsijaya, Desa Ujung Jaya dan Desa Leuwigede. Instrumen yang digunakan dalam penelitian ini yaitu lembar observasi dan lembar wawancara dengan calon kepala desa perempuan. Adapun hasil penelitian ini menunjukan bahwa pendidikan bukan menjadi faktor penentu utama keterlibatan perempuan untuk mencalonkan diri sebagai kepala desa, terdapat faktor lain yang mempengaruhi partisipasi politik perempuan dalam pemilihan kepala desa Tahun 2017 di Kecamatan Widasari antara dorongan dari suami, maupun pengalaman dalam organisasi.

Kata Kunci: pendidikan, partisipasi, perempuan, dan pemilihan kepala desa

\section{A. Pendahuluan}

Dalam masyarakat yang masih didominasi oleh budaya patriarkhi, perempuan seringkali dipandang hanya memiliki peran diwilayah privat atau ruang domestik sehingga dianggap tidak perlu memiliki pendidikan yang memadai karena setelah menyelesaikan pendidikan perempuan hanya akan berperan didalam rumah. Dalam masyarakat Indramayu, peran perempuan tersebut dengan jelas dinyatakan dalam ungkapan "dapur, kasur, dan sumur". Adanya pemisahan peran yang signifikan antara laki-laki dan perempuan menciptakan ketidakadilan gender, dimana laki-laki dilekatkan dengan peran-peran yang berhubungan dengan kegiatan-kegiatan diluar rumah (publik), sedangkan perempuan memiliki peran yang berkaitan dengan kegiatan rumah tangga. Pembagian peran tersebut melahirkan berbagai pembedaan perlakuan antara laki-laki dan perempuan baik berkaitan dengan kesempatan memperoleh pendidikan, maupun kegiatan-kegiatan di ranah publik, dimana lakilaki selalu memiliki kesempatan dan peluang lebih besar dalam memperoleh akses pendidikan maupun keterlibatan dalam berbagai kegiatan serta organisasi sosial atau politik. Sosialisasi atas peran- 
peran gender tersebut terlembagakan baik melalui institusi nonformal seperti keluarga dna masyarakat, maupun pada institusi formal, seperti pendidikan maupun tempat kerja. Kondisi ini menjadi salah satu faktor yang membatasi perempuan untuk terlibat dalam berbagai kegiatan politik yang salah satu bentuknya yaitu pencalonan perempuan pada jabatan-jabatan politik diberbagai tingkatan termasuk pada jabatan politik ditingkatan paling rendah yaitu desa. Sebagai warga negara, perempuan memiliki hak politik yang sama dengan laki-laki, namun pada tataran praktis, partisipasi perempuan dalam bidang politik masih rendah. Kondisi ini tercermin pada rendahnya keterlibatan perempuan di berbagai kontestasi politik baik ditingkat nasional, regional, maupun lokal. Sebagaimana yang berlangsung di Kecamatan Widasari Kabupaten Indramayu, pada pemilihan kepala desa tahun 2017, diantara empat desa yang menyelenggaran pemilihan kepala desa, yaitu Kongsijaya; Ujung Jaya; Kasmaran; Leuwigede, hanya ada tiga calon perempuan yang mendaftar sebagai calon kepala desa.

Berkaitan dengan partisipasi warga negara, baik laki-laki dan perempuan dalam pemilihan kepala desa telah diatur dalam Peraturan Menteri Dalam Negeri Republik Indonesia Nomor 65 Tahun 2017 Tentang Perubahan Atas Peraturan Menteri Dalam Negeri Nomor 112 Tahun 2014 Tentang Pemilihan Kepala Desa Pasal 21 bahwa "Calon kepala Desa wajib memenuhi persyaratan: (a) Warga negara Republik Indonesia; (b) Bertakwa kepada Tuhan Yang Maha Esa; (c) Memegang teguh dan mengamalkan pancasila, melaksanakan undang-undang dasar negara republik Indonesia Tahun 1945, serta mempertahankan dan memelihara keutuhan Negara Kesatuan Republik Indonesia dan Bhinneka Tunggal Ika; (d) Berpendidikan paling rendah tamat sekolah menengah pertama atau sederajat; (e) Berusia paling rendah 25 (dua puluh lima) tahun pada saat mendaftar; (f) Bersedia dicalonkan menjadi kepala Desa. ${ }^{1}$

1 Peraturan Menteri Dalam Negeri Republik Indonesia Nomor 65 Tahun 2017 Tentang Perubahan Atas Peraturan Menteri Dalam Negeri Nomor 112 Tahun 2014 Tentang Pemilihan Kepala Desa Pasal 21 
Dari pasal tersebut diketahui bahwa setiap warga negara memiliki kesempatan yang sama untuk mencalonkan diri sebagai kepala desa selama ia memenuhi persyaratan yang berlaku yaitu merupakan warga negara Indonesia, bertakawa kepada Tuhan YME, setia pada Pancasila, melaksanakan konstitusi negara, menjaga perdamaian, berpendidikan minimal sekolah menengah pertama, dan berusia minimal 25 tahun, bersedia dicalonkan sebagai kepala desa, dll. Meskipun dijamin dalam kepmendagri tersebut bahwa setiap warga negara dalam hal ini baik laki-laki maupun perempuan berhak mencalonkan diri sebagai calon kepala desa selama memenuhi persyaratan yang ditentukan, namun pada tataran praktis, perempuan hanya menjadi kelompok minoritas yang turut berpartisipasi secara aktif yaitu mencalonkan diri sebagai calon kepala desa dalam pemilihan kepala desa yang berlangsung di Kecamatan Widasari tahun 2017. Atas dasar tersebut, peneliti bermaksud melakukan penenitian untuk menganalisa apakah jenjang pendidikan kandidat perempuan calon kepala desa di Kecamatan Widasari menjadi penentu keikutsertaan mereka pada pemilihan kepala desa tahun 2017 di Kecamatan Widasari.

Penelitian ini menggunakan pendekatan kualitatif dengan metode studi kasus. Penelitian kasus memusatkan perhatian pada suatu kasus secara intensif dan terperinci mengenai latar belakang keadaan sekarang yang dipermasalahkan. ${ }^{2}$ Selain itu, penelitian tindakan kasus dimaknai juga sebagai penelitian dimana peneliti mencoba menggambarkan subyek penelitian didalam keseluruhan tingkah laku, yakni tingkah laku itu sendiri beserta hal-hal yang melingkupinya, hubungan antara tingkah laku dengan riwayat timbulnya tingkah laku, demikian pula lain-lain hal yang berkaitan dengan tingkah laku tersebut. ${ }^{3}$ Dalam penelitian ini, subyek penelitian adalah calon kepala desa (kuwu) perempuan di Kecamatan Widasari, h. 9.

2 Margono, Metodologi Penelitian Pendidikan, (Jakarta: Rineke Cipta, 2010),

3 Suharsimi Arikunto, Manajemen Penelitian, (Jakarta: Rineke Cipta, 2009), h. 238 
dari empat desa yang menyelenggarakan pemilihan kepala desa, hanya tiga desa yang memiliki calon kepala desa perempuan yaitu Desa Kongsijaya, Desa Ujung Jaya, dan Desa Leuwigede. Dalam penelitian studi kasus, teknik memperoleh data sangat komprehensif seperti observasi perilaku, wawancara, analisis dokumenter, tes, dan lain-lain, bergantung pada kasus yang dipelajari. ${ }^{4}$ Adapun instrumen penelitian yang digunakan antara lain wawancara dengan calon kuwu perempuan, dan observasi selama masa kampanye dan saat pemilihan kepala desa tanggal 15 Desember 2017 lalu.

\section{B. Pendidikan dan Hak Setiap Warga Negara}

Pendidikan merupakan salah satu unsur penting dalam menjamin kemajuan suatu bangsa, terkait dengan pendidikan, dalam UU No. 20 Tahun 2003 tentang Sisdiknas pasal I ayat (1) disebutkan bahwa "Pendidikan merupakan usaha sadar dan terencana untuk mewujudkan suasana belajar dan proses pembelajaran agar peserta didik secara aktif mengembangkan potensi dirinya untuk memiliki kekuatan spiritual keagamaan, pengendalian diri, kepribadian, kecerdasan, akhlak mulia, serta keterampilan yang diperlukan dirinya, masyarakat, bangsa dan negara”. Dalam pasal ini, diketahui bahwa pendidikan merupakan suatu usaha yang sengaja dirancang untuk menyelenggarakan kegiatan pembelajaran sehingga siswa terlibat secara aktif dalam proses pengembangan semua potensi dirinya secara maksimal sehingga dapat memberikan kontribusi positif tidak hanya untuk diri sendiri namun juga untuk masyarakat, bangsa dan negara. Pendidikan merupakan hak setiap warga negara, sebagaimana diatur dalam UUD 1945 pasal 31 ayat (1) "setiap warga negara berhak mendapatkan pendidikan".5 Dapat disimpulkan bahwa setiap warga negara tanpa membedakan jenis kelamin, status sosial, ekonomi, maupun latar belakang ras, suku, dll memiliki kesamaan hak untuk memperoleh pendidikan.

\footnotetext{
4 Nana Sudjana dan Ibrahim, Penelitian dan Penilaian Pendidikan, (Bandung: Sinar Baru Algensindo, 2012), h. 69

5 Lihat UUD 1945 pasal 31 ayat (1)
} 
Meskipun pemerintah telah menjamin hak warga negara untuk mendapatkan pendidikan, namun tidak setiap warga negara memiliki kesempatan yang sama untuk mendapatkan pendidikan karena berbagai hambatan, salah satunya adalah hambatan kultural terutama dihadapi oleh perempuan, yang dianggap tidak membutuhkan pendidikan tinggi karena hanya akan berperan diwilayah domestik. Tidak sedikit perempuan yang hanya mengenyam pendidikan formal ditingkatan dasar atau menegah, hanya sedikit yang berkesempatan memperoleh pendidikan tinggi.

Berkaitan dengan pendidikan formal, telah disebutkan bahwa "Pendidikan formal merupakan jalur pendidikan yang terstruktur dan berjenjang yang terdiri atas pendidikan dasar, pendidikan menengah, dan pendidikan tinggi". ${ }^{6}$ Jalur pendidikan formal berjenjang dari tingkatan dasar hingga perguruan tinggi. Adapun jenjang pendidikan dasar merupakan jenjang pendidikan awal yang harus di lampaui oleh seluruh peserta didik sebelum masuk ke jenjang pendidikan selanjutnya, sebagaimana diatur dalam UU No. 20 Tahun 2003 tentang Sisdikna Pasal 17 ayat (1) bahwa "Pendidikan dasar merupakan jenjang pendidikan yang melandasi jenjang pendidikan menengah"; (2) Pendidikan dasar berbentuk sekolah dasar (SD) dan madrasah ibtidaiyah (MI) atau bentuk lain yang sederajat serta sekolah menengah pertama (SMP) dan madrasah tsanawiyah (MTs), atau bentuk lain yang sederajat".

Adapun aturan mengenai pendidikan menengah terdapat pada Pasal 18 UU Sisdiknas yang menyebutkan bahwa "(1) Pendidikan menengah merupakan lanjutan pendidikan dasar; (2) Pendidikan menengah terdiri atas pendidikan menengah umum dan pendidikan menengah kejuruan; (3) Pendidikan menengah berbentuk sekolah menengah atas (SMA), madrasah aliyah (MA), sekolah menengah kejuruan (SMK), dan madrasah aliyah kejuruan (MAK), atau bentuk lain yang sederajat". Setelah peserta didik penempuh pendidikan

${ }^{6}$ Lihat Undang-Undang Nomor. 20 Tahun 2003 Tentang Sistem Pendidikan Nasional (Sisdiknas) Pasal I ayat 11 
dasar dan menengah, peserta didik memiliki pilihan untuk melanjutkan pendidikan ke jenjang pendidikan yang lebih tinggi sehingga pemahaman dan penguasaan ilmunya semakin luas dan mendalam. Sementara itu, ketentuan yang berkaitan dengan pendidikan tinggi telah diatur di dalam pasal 19 UU Sisdiknas yang menyebutkan bahwa; (1) Pendidikan tinggi merupakan jenjang pendidikan setelah pendidikan menengah yang mencakup program pendidikan diploma, sarjana, magister, spesialis, dan doktor yang di selenggarakan oleh pendidikan tinggi; (2) Pendidikan tinggi diselenggarakan dengan sistem terbuka".

Dengan menempuh pendidikan tinggi, maka kesempatan seseorang untuk berpartisipasi dalam ranah publik baik pada instansi pemerintah, swasta maupun institusi lainnya yang berkenaan dengan latar belakang pendidikan yang dimilikinya. Sejalan dengan UU Sisdiknas mengenai pasal-pasal tentang tingkatan pendidikan jenjang pendidikan adalah tahap pendidikan yang berkelanjutan, yang ditetapkan berdasarkan tingkat perkembangan peserta didik, tingkat kerumitan bahan pengajaran dan cara menyajikan bahan pengajaran. Jenjang pendidikan sekolah terdiri dari pendidikan dasar, pendidikan menengah, dan pendidikan tinggi. Disamping jenjang pendidikan itu dapat diadakan pendidikan pra sekolah, yang tidak merupakan prasyarat untuk memasuki pendidikan dasar. ${ }^{7}$

Berdasarkan pendapat tersebut, dapat diketahui bahwa pendidikan formal diselenggarakan mengikuti perkembangan peserta didik yakni meliputi pendidikan dasar diperuntukan bagi anak-anak untuk memperoleh pengetahuan yang bersifat dasar, pendidikan menengah yang bersifat lanjutan dan pendidikan tinggi untuk mencapai kemampuan dan keterampilan profesional.

Lebih lanjut dikemukakan bahwa jenjang pendidikan dapat dibagi menjadi tiga, yaitu:

7 Fuad Ihsan, Dasar-Dasar Kependidikan, (Jakarta: PT Rineka Cipta, 2013), h. 
(a) Pendidikan Dasar. Pendidikan dasar merupakan pendidikan yang memberikan pengetahuan dan keterampilan, menum-buhkan sikap dasar yang diperlukan dalam masyarakat, serta mempersiapkan peserta didik untuk mengikuti pendidikan menengah.

(b) Pendidikan Menengah. Pendidikan menengah merupakan pendidikan yang mempersiapkan peserta didik menjadi anggota masyarakat yang memiliki kemampuan mengadakan hubungan timbal-balik dengan lingkungan, sosial budaya dan alam sekitar, serta dapat mengembangkan kemampuan lebih lanjut dalam dunia kerja atau pendidikan tinggi.

(c) Pendidikan Tinggi. Pendidikan tinggi adalah pendidikan yang mempersiapkan peserta didik untuk menjadi anggota masyarakat yang memiliki tingkat kemampuan tinggi yang bersifat akademik dan atau professional sehingga dapat menerapkan, mengembangkan dan atau menciptakan ilmu pengetahuan, tekhnologi dan seni dalam rangka pembangunan nasional serta meningkatkan kesejahteraan manusia. ${ }^{8}$

Berdasarkan pemaparan di atas, dipahami bahwa pendidikan dasar merupakan salah satu jenjang pendidikan paling rendah yang menjadi landasan untuk mengikuti pendidikan selanjutnya, pada tingkatan ini siswa dipersiapkan untuk mengembangkan potensi dirinya baik berkaitan dengan pengetahuan maupun keterampilan yang diperlukan sebagai bagian dari anggora masyarakat. Sedangkan pendidikan menengah memberikan kesempatan pada siswa untuk memiliki pengetahuan dan keterampilan yang lebih luas dan kompleks sehingga ia mampu memberikan kemanfaatan pada lingkungan sosialnya memlalui berbagai peran-peran yang diperoleh setelah lulus sekolah. Adapun pendidikan tinggi merupakan jenjang pendidikan yang mempersiapkan pesertanya menjadi seorang profesional serta berperan dalam mengembangkan dan menciptakan

8 Fuad Ihsan, Dasar-Dasar Kependidikan..., h. 22; lihat juga dalam Kepmendikbud No. 0186/P/1984. 
ilmu pengetahuan, teknologi maupun seni yang bermanfaat bagi kemajuan dan kesejahteraan masyarakat.

Terdapat tiga kendala bagi pendidikan perempuan yiatu iklim ekonomi, sikap sosial, dan lingkungan sekolah. ${ }^{9}$ Apa yang disampaikan Mosse dalam Womankind tersebut menggambarkan bahwa masih banyak kendala yang dihadapi perempuan untuk mendapatkan akses terhadap pendidikan baik hambatan ekonomi, hambatan budaya berupa sikap sosial yang menafikan peran perempuan dalam ranah publik, maupun lingkungan sekolah yang seringkali menguatkan peran-peran gender pada peserta didiknya. Apa yang dikemukakan Womankind tersebut dialami oleh banyak perempuan dari berbagai belahan dunia.

"Sex differences in intellectual skills be explained by the different role expectations placed on men and women in society. Girls, who are expected to be more oriented toward others, do best at skills requiring contextual understanding. They have more facility with verbal reasoning, perhaps because of the expectation that they will be talkers, not thinkers. On the other hand, boys, who are expected to move into csientific and technical profession and tobe in a position a manipulate and control environment, are more likely to learn skills of abstract reasoning and intellectual detechment that allow them to enter such roles."10

Berdasarkan pada pernyataan Anderson tersebut, tergambar bahwa dalam dunia pendidikan, perlakuan yang tidak setara antara laki-laki dan perempuan khususnya terkait dengan ekspektasi kemampuan yang dimiliki oleh siswa laki-laki dan siswa perempuan sering kali ditunjukan khususnya oleh guru maupun stakeholder sekolah lainnya.

Meskipun pemerintah telah mengatur mengenai jenjang pendidikan dan bahwa setiap warga negara berkesempatan dan

9 NGO Womankind dalam Cleves Julia Mosse, Gender dan Pembangunan, (Yogyakarta: Pustaka Pelajar, 2007), h. 102.

10 L. Margaret Anderson, Thingking About Women Sociological and Feminist Perspectives, (New York: Macmillan Publishing Co.,Inc. 1983), h. 61 
berhak untuk mendapatkan pendidikan minimal dua belas tahun, namun tidak semua warga negara mendapatkan kesempatan yang sama. Selain mengenai akses dan kesempatan yang seringkali tidak sama antara laki-laki dan perempuan, kondisi lain yang seringkali ditemukan dalam lembaga pendidikan yaitu berupa internalisasi peran-peran gender baik melalui buku ajar yang digunakan dalam proses pembelajaran, maupun penjelasan atau ceramah yang disampaikan oleh guru, maupun dalam proses sosialisasi yang terbangun dalam kegiatan fomal maupun non-formal yang terbangun disekolah. Sebagai tempat bersosialisasi, sekolah adalah institusi utama tempat konstruksi gender dipraktekkan. ${ }^{11}$

Berdasarkan pada gambaran di atas, dipahami bahwa seringkali lembaga pendidikan menguatkan peran-peran gender yang dilekatkan pada laki-laki dan perempuan yang cenderung bersifat diskriminatif dan merugikan salah satu pihak, terutama perempuan, selain itu, karena peran-peran gender yang cenderung menempatkan perempuan diranah privat, mengakibatkan akses pendidikan antara laki-laki dan perempuan seringkali berbeda. Anak-anak gadis mendapatkan pendidikan ala akadarnya atau tidak sama sekali, sangat berat menghadapi dunia. Mereka tidak memiliki sumber daya yang memungkinkannya secara efektif mengatasi kemiskinannya. ${ }^{12}$

Apa yang disampaikan oleh Mosse tersebut, menggambarkan bahwa seringkali kesempatan mendapatkan pendidikan lebih diprioritaskan pada pada anak laki-laki dibandingkan anak perempuan. Dengan terbatasnya kesempatan untuk mendapatkan pendidikan secara maksimal, perempuan seringkali tersisih atau tidak mengambil banyak kesempatan untuk berpartisipasi dalam berbagai kegiatan diranah publik, khususnya berpartisipasi dalam bidang politik. partisipasi politik sebagai bagian yang tidak terpisahkan dalam sistem pemerintahan demokrasi memerlukan dukungan dari seluruh

11 Sugihastuti dan Hadi Itsna Septiawan, Gender \& Inferioritas Perempuan, (Yogyakarta: Pustaka Pelajar, 2010), h. 67.

12 Mosse, Gender dan Pembangunan..., h. 101. 
stakeholder khususnya warga negara untuk menjadi bagian dalam sistem demokrasi yang berlangsung di Indonesia.

\section{Perempuan dan Partisipasi Politik}

Terkait dengan partisipasi politik, dinyatakan bahwa partisipasi politik adalah kegiatan-kegiatan suka rela dari warga masyarakat melalui mana mereka mengambil bagian dalam proses pemilihan penguasa, dan secara langsung atau tidak langsung, dalam proses pembentukan kebijakan umum. ${ }^{13}$

Dari pengertian di atas, dapat disimpulkan bahwa partisipasi politik merupakan kegiatan yang secara sukarela terlibat dalam berbagai kegiatan politik baik secara langsung maupun tidak langsung. Partisipasi politik dipahami juga sebagai "kegiatan pribadi warga negara yang legal yang sedikit banyak langsung bertujuan untuk mempengaruhi seleksi pejabat-pejabat negara dan/atau tindakan-tindakan yang diambil oleh mereka".14

Berdasarkan pendapat Nie dan Verba tersebut, dapat di pahami bahwa partisipasi merupakan kegiatan warga negara yang sesuai dengan aturan mengenai berbagai kegiatan yang ditujukan untuk mempengaruhi pemilihan pejabat-pejabat negara maupun tindakan-tindakan yang dilakukan oleh mereka. Adapun cakupan partisipasi politik dijabarkan sebagai berikut, "partisipasi politik mencakup tidak hanya kegiatan yang oleh pelakunya sendiri dimaksudkan untuk mempengaruhi pengambilan keputusan pemerintah, akan tetapi juga kegiatan yang oleh orang lain diluar si pelaku dimaksudkan untuk mempengaruhi pengambilan keputusan pemerintah". 15

Menurut Huntington dan Nelson bertentangan dengan pendapat Nie dan Verba. Menurut Huntington dan Nelson partisipasi

13 McClosky dalam Meriam Budiarjo, Partisipasi dan partai Politik sebuah Bunga Rampai, (Jakarta: Gramedia, 1981), h. 1

14 Lihat Nie dan Verba dalam Budiarjo, Partisipasi dan partai Politik sebuah Bunga Rampai... h. 1

15 Samuel Huntington dan Joan Nelson, Partisipasi Politik di Negara Berkembang, (Jakarta: Rineke Cipta, 1994), h. 9. 
politik yang dilakukan pemerintah tidak hanya berbentuk kegiatankegiatan politik yang resmi, namun kegiatan politik yang dianggap tidak prosedural atau bertentangga dengan aturan dianggap sebagai partisipasi politik juga.

Adapun bentuk-bentuk partisipasi politik, sebagai berikut: "kegiatan pemilihan mencakup suara, sumbangan-sumbangan untuk kampanye, bekerja dalam suatu pemilihan, mencari dukungan bagi seorang calon, atau setiap tindakan yang bertujuan mempengaruhi hasil proses pemilu; lobbying mencakup upaya-upaya perorangan atau kelompok untuk menghubungi pejabat-pejabat pemerintah dan pemimpin-pemimpin politik dengan maksud mempengaruhi keputusan-keputusan mereka mengenai persoalan-persoalan yang menyangkut sejumlah besar orang; kegiatan organisasi menyangkut partisipasi sebagai anggota atau pejabat dalam suatu organisasi yang tujuannya yang utama dan eksplisit adalah mempengaruhi keputusan pemerintah; mencari koneksi (contacting) merupakan tindakan perorangan yang ditujukan terhadap pejabat-pejabat pemerintah dan biasanya dengan maksud memperoleh manfaat bagi hanya satu orang atau segelintir orang; tindak kekerasan (violance) juga dapat merupakan satu bentuk partisipasi politik".16

Berdasarkan pada pendapat di atas, dapat disimpulkan bahwa partisipasi politik memiliki banyak bentuk dengan intensitas yang beragam, antara lain ikut serta dalam pemilihan umum untuk memberikan suara, teribat dalam pendanaan atau sumbangan lainnya kepada salah satu kandidat dalam kampanye, bekerja dalam kegiatan pemilihan, serta kegiatan-kegiatan lain yang bertujuan mempenagruhi hasil pemilihan, bentuk lain partisipasi politik yaitu kegiatan menghubungi penentu kebijakan dan pembuat aturan baik dilakukan secara perorangan maupun kelompok untuk mem-pengaruhi keputusan mereka; menjadi anggota atau pengurus dalam suatu organisasi atau kelompok kepentingan merupakan bagian dari bentuk partisipasi politik; dan mencari koneksi kepada pejabat-pejabat

${ }^{16}$ Huntington \& Nelson, Partisipasi Politik di Negara Berkembang... h. 16. 
pemerintah yang dilakukan seseorang untuk memperoleh manfaat bagi dirinya sendiri dianggap sebagai partisipasi politik. Hal ini dapat digambarkan pada piramida berikut ini: ${ }^{17}$

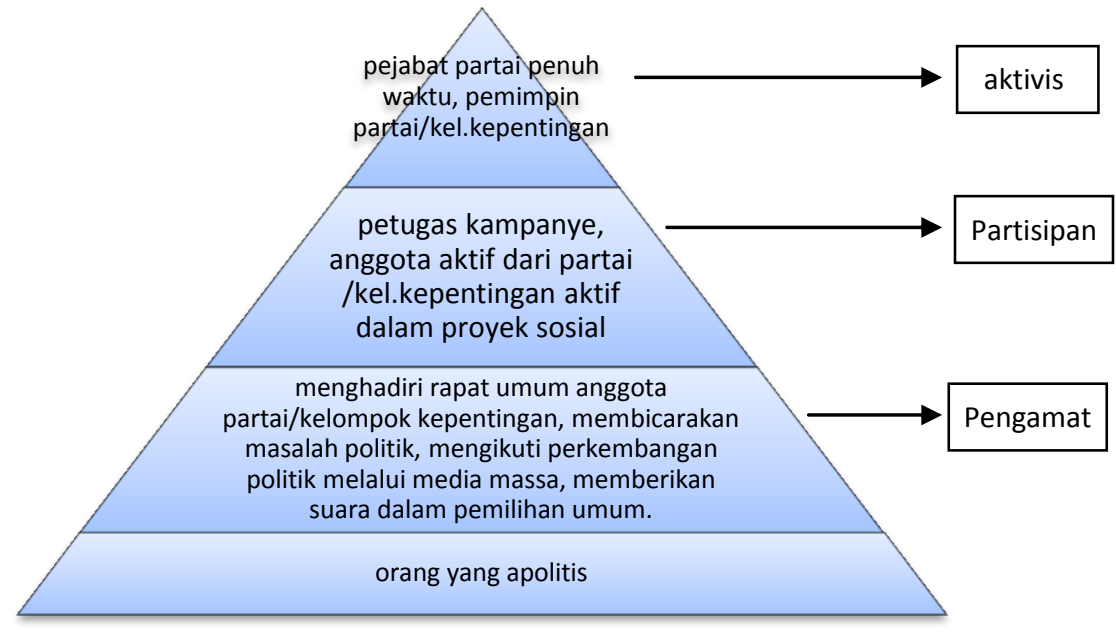

Partisipasi politik warga negara berkaitan dengan hak politik yang dimiliki oleh warga negara. hak politik adalah hak yang ditetapkan dan diakui oleh undang-undang dasar atau konstitusi suatu negara berdasarkan keanggotaan seseorang sebagai warga negara. ${ }^{18}$ Warga negara memiliki hak politik yang diatur dalam konstitusi, atas dasar hak tersebut, warga negara dapat berpartisipasi secara politik dalam berbagai bentuk sebagaimana yang diatur dalam konstitusi.

Lebih lanjut menurut Mulia, hak politik tersebut antara lain; (1) hak untuk mengungkapkan pendapat dalam pemilihan umum dan referendum; (2) hak untuk mencalonkan diri sebagai anggota lembaga perwakilan rakyat; (3) hak mencalonkan diri sebagai presiden dan hal-hal lain berkenaan dengan politik. Hak-hak politik menyiratkan partisipasi individu dalam pembentukan pendapat umum, baik dalam

17 F. Roth dan L. Wilson, The Comparative Study Of Politics, (Boston: Houghton Miffin Company, 1976), h. 159 dalam Budiarjo, h. 6

18 Musda Mulia, Menuju Kemandirian Politik Perempuan, (Yogyakarta: Kibar press, 2007), h. 181 
pemilihan wakil-wakil mereka didalam lembaga perwakilan rakyat, atau pencalonan diri mereka untuk menjadi anggota lembaga perwakilan tersebut. Atas dasar pendapat tersebut, partisipasi politik memiliki berbagai bentuk dari sekadar memberikan suara saat pemilu maupun referendum, men-calonkan diri untuk menduduki jabatan politik baik pada tingkatan pusat, maupun lokal, atau mencalonkan diri sebagai anggota perwakilan rakyat.

Hak politik yang dimiliki oleh warga negara secara eksplisit dinyatakan dalam Undang-Undang No. 39 Tahun 1999 Tentang Hak Asasi Manusia Pasal 43 ayat (1), yaitu bahwa "setiap warga negara berhak untuk dipilih dan memilih dalam pemilihan umum bersamaan persamaan hak melalui pemungutan suara yang langsung, umum, bebas, rahasia, jujur, dan adil sesuai dengan ketentuan peraturan perundang-undangan". 19

Atas dasar undang-undang tentang hak asasi manusia tersebut, diketahui bahwa setiap warga negara memiliki hak yang sama untuk dipilih dan memilih dalam berbagai kegiatan pemilihan umum diberbagai tingkatan baik lokal, regional, maupun nasional. Adapun mengenai hak perempuan untuk ikut berpartisipasi dalam kegiatan pemilihan umum dinyatakan secara eksplisit dalam undangundang lain disebutkan, bahwa "wanita berhak untuk memilih, dipilih, diangkat, dalam pekerjaan, jabatan, dan profesi sesuai dengan persyaratan dan peraturan perundang-undangan".20 Berdasarkan Pasal 49 itu, dapat diketahui bahwa perempuan memiliki hak berpartisipasi dalam kegiatan politik baik untuk memilih dalam pemilihan umum, mengajukan diri sebagai calon dalam pemilihan baik pada tingkatan lokal, regional, maupun nasional.

\section{Hasil Penelitian dan Pembahasan}

Berdasarkan pada data hasil penelitian dapat dianalisa bahwa, tingkat pendidikan dari ketiga calon Kepala Desa perempuan tersebut

\footnotetext{
${ }^{19}$ Lihat UU No. 39 Tahun 1999 Tentang Hak Asasi Manusia Pasal 43 ayat 1

20 Lihat UU No. 39 Tahun 1999 Tentang Hak Asasi Manusia Pasal 49 ayat (1), yaitu
} 
sangat bervariatif; yaitu untuk Desa Kongsijaya berpendidikan akhir Sekolah Menengah Atas (SMA), untuk calon Kepala Desa Ujung Jaya berpendidikan Sekolah Menengah Pertama (SMP), untuk Calon Kepala Desa Leuwigede berpendidikan Sekolah Menengah Kejuruan (SMK).

Jika data tersebut dikaitkan dengan berbagai jenjang pendidikan sebagaimana yang telah dikemukakan Ihsan, yakni Jenjang pendidikan sekolah terdiri dari pendidikan dasar, pendidikan menengah, dan pendidikan tinggi ${ }^{21}$, maka dari data tersebut dapat diketahui bahwa ketiga calon tidak ada yang memiliki jenjang pendidikan tinggi. Dapat diketahui pula bahwa tingkat pendidikan bukan merupakan faktor utama seorang perempuan mencalonkan diri sebagai kepala desa, ada faktor lain yang mendorong keterlibatan peremuan pada kegiatan politik dalam hal ini pencalonan diri sebagai calon kepala desa.

Secara umum, dan khususnya di Kabupeten Indramayu, akses perempuan untuk memperoleh pendidikan tinggi masih dibatasi oleh hambatan kultural maupuan sosial. Kondisi ini sejalan dengan pendapat yang dikemukakan Mosse bahwa "Anak-anak gadis hanya mendapatkan pendidikan ala akadarnya atau tidak sama sekali, sangat berat menghadapi dunia. Mereka tidak memiliki sumber daya yang memungkinkannya secara efektif mengatasi kemiskinannya" ${ }^{22}$

Berdasarkan pada data penelitian menegaskan pendapat yang dikemukakan Mosse, di antara tiga responden yang mencalonkan diri sebagai calon kepala desa, tidak ada yang mengenyam pendidikan tinggi, hanya dua kandidat kepala desa memperoleh pendidikan menengah atas (SMA dan yang sederajat) yaitu Calon Kepala Desa Leuwigede dan Calon Kepala Desa Kongsijaya, sedangkan untuk Calon Kepala Desa Ujung Jaya mendapatkan pendidikan tingkat sekolah menegah pertama melalui kejar paket. Masih kuatnya anggapan akan posisi perempuan yang lebih rendah dibandikan dengan laki-laki menjadi penghambat bagi banyak anak-anak perempuan untuk

21 Fuad Ihsan, Dasar-Dasar Kependidikan..., h. 22

22 Mosse, Gender dan Pembangunan..., h. 101. 
memperoleh pendidikan ke jenjang yang lebih tinggi untuk mengembangkan potensi yang dimiliki dan untuk memberikan kontribusi yang signifikan bagi kehidupan keluarga, masyarakat, bangsa dan negara.

Ketika potensi yang dimiliki tidak dapat dikembangkan secara maksimal karena akses dan kesempatan yang terbatas, maka banyak perempuan yang menganggap dirinya tidak memiliki cukup kemampuan dan kepercayaan diri untuk melakukan kerja-kerja di ranah publik. Sehingga sebagian besar perempuan enggan untuk terlibat dalam berbagai kegiatan publik maupun politik. Dan ketika perempuan teribat dalam kegiatan publik maupun politik, tidak semuanya muncul dari kesadaran pribadi akan eksistensi dirinya sebagai perempuan atau bagian dari upaya membangun kesetaraan gender. Tidak sedikit dari perempuan yang terlibat dalam kegitan politik yang mengikuti kegiatan tersebut karena dorongan pihak lain, khususnya suami.

Sebagaimana data yang diperoleh dalam penelitian ini, yakni responden dari Desa Kongsijaya dan Desa Ujung Jaya, menyatakan bahwa kesediaan mereka untuk dicalonkan sebagai kepala desa di dorong oleh suami mereka. Atas informasi tersebut, diketahui bahwa keterlibatan perempuan dalam partisipasi politik lokal, dalam hal ini terlibat dalam pencalonan sebagai kepala desa bukan merupakan inisiatif mereka sendiri, namun masih atas dorongan pihak lain, dalam hal ini suami. Kondisi ini menggambarkan bahwa masih banyak kandidat perempuan yang terlibat dalam berbagai kegiatan politik bukan karena kesadaran gender akan kesetaraan kesempatan maupun akses dalam semua bidang termasuk politik. Untuk Desa Kongsijaya, responden bersedia dicalonkan sebagai kepala desa untuk mengamankan pencalonan suami yang terlebih dulu mendaftar sebagai calon kepala desa, dan berdasarkan peraturan yang mengharuskan calon kepala desa minimal dua calon dan maksimal lima calon. Sehingga pencalonan responden sebagai calon kepala desa bukan atas dasar kesadaran pribadi dan motivasi diri untuk terlibat 
secara aktif dalam politik lokal, namun lebih pada dipengaruhi oleh faktor lain di luar dirinya yakni keluarga khususnya suami.

Responden dari Desa Ujung Jaya yang mencalonkan diri bukan karena pemahaman akan pentingnya partisipasi politik perempuan dan motivasi pribadi untuk terlibat dalam kegiatan politik, namun karena dorongan suami yang tidak bisa mencalonkan diri sebagai kepala desa karena terhalang tingkat pendidikan akhir yang hanya sekolah dasar. Adapun untuk responden dari Desa Leuwigede, meskipun tingkat pendidikan terkahir sekolah menengah kejuruan, responden memiliki pengalaman dalam organisasi kepemudaan selama hampir delapan tahun, sehingga memiliki kepercayaan diri untuk mencalonkan diri sebagai calon Kepala Desa Leuwigede, disamping itu, beliau memiliki kemandirian secara ekonomi karena merupakan seorang kontraktor dan pencalonannya diperkuat oleh dukungan suami.

Keterlibatan semua responden dalam pemilihan kepala desa merupakan bagian dari partisipasi politik yang merupakan hak warga negara yang dijamin dalam konstitusi. Sebagaimana yang dinyatakan oleh Muria, bahwa Partisipasi politik warga negara berkaitan dengan hak politik yang dimiliki oleh warga negara. hak politik adalah hak yang ditetapkan dan diakui oleh undang-undang dasar atau konstitusi suatu negara berdasarkan keanggotaan seseorang sebagai warga negara. $^{23}$ Keikutsertaan responden dalam pemilihan kepala desa merupakan wujud nyata dari penggunaan hak politik yang sudah diatur dalam konstitusi. Bahwa setiap warga negera baik laki-laki dan perempuan memiliki hak politik yang sama, namun dalam kenyataannya perempuan memiliki kesempatan dan akses yang terbatas untuk menggunakan hak politik yang mereka miliki karena berbagai hambatan dan batasan sosial kultural, sehingga perempuan cenderung hanya berkutat dengan aktivitas domestik yang cenderung tidak dianggap penting. Meskipun banyak kegiatan politik yang dapat diikuti dan melibatkan perempuan, namun belum dalam

${ }^{23}$ Mulia, Menuju Kemandirian politik Perempuan...h. 181. 
dimanfaatkan secara maksimal oleh perempuan. Sebagaimana disampaikan McClosky, bahwa partisipasi politik adalah kegiatankegiatan suka rela dari warga masyarakat melalui mana mereka mengambil bagian dalam proses pemilihan penguasa, dan secara langsung atau tidak langsung, dalam proses pembentukan kebijakan umum. ${ }^{24}$

Ketika responden mencalonkan diri sebagai kepala desa, itu merupakan wujud partisipasi politik aktif yang dilakukan. Terkait dengan hak politik, terdapat berbagai macam bentuk, yaitu: (1) hak untuk mengungkapkan pendapat dalam pemilihan umum dan referendum; (2) hak untuk mencalonkan diri sebagai anggota lembaga perwakilan rakyat; (3) hak mencalonkan diri sebagai presiden dan hal-hal lain berkenaan dengan politik. Hak-hak politik menyiratkan partisipasi individu dalam pembentukan pendapat umum, baik dalam pemilihan wakil-wakil mereka didalam lembaga perwakilan rakyat, atau pencalonan diri mereka untuk menjadi anggota lembaga perwakilan tersebut. ${ }^{25}$

Keikutsertaan responden dalam pemilihan kepala desa merupakan representasi dari penggunaan hak politik khususnya hak mencalonkan diri dalam jabatan politik atau publik. Jaminan akan hak warga negara baik laki-laki maupun perempuan untuk berpartisipasi dalam kegiatan politik khususnya berkenaan dengan hak untuk dipilih dan memilih secara eksplisit diatur dalam Undang-Undang No. 39 Tahun 1999 Tentang Hak Asasi Manusia pasal. 43 ayat (1) dinyatakan bahwa "setiap warga negara berhak untuk dipilih dan memilih dalam pemilihan umum bersamaan persamaan hak melalui pemungutan suara yang langsung, umum, bebas, rahasia, jujur, dan adil sesuai dengan ketentuan peraturan perundang-undangan".

Adapun hak perempuan untuk terlibat dalam kegiatan politik maupun kegiatan publik secara spesifik dinyatakan dalam UndangUndang No. 39 Tahun 1999 Tentang Hak Asasi Manusia pasal. 49 ayat

24 McClosky dalam Meriam Budiarjo, Partisipasi dan partai Politik sebuah Bunga Rampai..., h. 1.

25 Mulia, Menuju Kemandirian politik Perempuan..., h. 181. 
(1): "wanita berhak untuk memilih, dipilih, diangkat, dalam pekerjaan, jabatan, dan profesi sesuai dengan persyaratan dan peraturan perundang-undangan". Pasal tersebut menjadi salah satu jaminan bagi perempuan untuk dapat secara aktif mengikuti berbagai kegiatan publik maupun politik yang dihendaki sesuai dengan pilihan nuraninya. Keterlibatan para responden dalam pencalonan sebagai kepala desa merupakan perwujudan dari hak politik perempuan, meskipun keterlibatan mereka dalam kegiatan politik yaitu pencalonan kepala desa lebih di dasarkan atas dorongan pihak lain bukan merupakan kehendak pribadi mereka sendiri.

Dan secara lebih luas, masih sangat banyak perempuan yang belum memiliki pemahaman akan kesetaraan perempuan untuk terlibat aktif dalam politik maupun kegiatan publik sebagaimana halnya laki-laki. Terdapat banyak kegiatan yang masuk kategori partisipasi dalam bidang politik yang dapat diikuti oleh warga negara baik laki-laki maupun perempuan. Sebagaimana dikemukakan oleh Huntington \& Nelson, bahwa "kegiatan pemilihan mencakup suara, sumbangan-sumbangan untuk kampanye, bekerja dalam suatu pemilihan, mencari dukungan bagi seorang calon, atau setiap tindakan yang bertujuan mempengaruhi hasil proses pemilu; lobbying mencakup upaya-upaya perorangan atau kelompok untuk menghubungi pejabat-pejabat pemerintah dan pemimpin-pemimpin politik dengan maksud mempengaruhi keputusan-keputusan mereka mengenai persoalan-persoalan yang menyangkut sejumlah besar orang; kegiatan organisasi menyangkut partisipasi sebagai anggota atau pejabat dalam suatu organisasi yang tujuannya yang utama dan eksplisit adalah mempengaruhi keputusan pemerintah; mencari koneksi (contacting) merupakan tindakan perorangan yang ditujukan terhadap pejabat-pejabat pemerintah dan biasanya dengan maksud memperoleh manfaat bagi hanya satu orang atau segelintir orang; tindak kekerasan (violance) juga dapat merupakan satu bentuk partisipasi politik". ${ }^{26}$

\footnotetext{
${ }^{26}$ Huntington \& Nelson, Partisipasi Politik di Negara Berkembang... h. 16.
} 
Berbagai kegiatan politik tersebut selama ini selalu didominasi oleh laki-laki, meskipun secara legal formal warga negara laki-laki dan perempuan memiliki hak yang sama untuk berpartisipasi secara politik, namun kenyataanya perempuan masih menghadapi hambatan personal, sosial maupun kultural. Melalui akses pendidikan yang lebih tinggi pada perempuan diharapkan dapat mendorong keterlibatan perempuan dalam ranah politik dan publik, sehingga keterlibatan perempuan dalam ranah politik maupun publik bukan semata-mata atas dorongan pihak lain, namun atas keinginan sendiri untuk berbartisipasi dan memberikan kontirbusi positif bagi kehidupan masyarakat, bangsa dan negara.

\section{E. Kesimpulan}

Dari data yang telah dikumpulkan dalam penelitian ini, dapat disimpulkan bahwa pendidikan tidak menjadi faktor penentu yang mempengaruhi partisipasi politik perempuan dalam pemilihan kepala desa di Kecamatan Widasari tahun 2017. Keterlibatan perempuan dalam kontestarlibatasi politik ditingkatan lokal dipenagruhi oleh dorongan suami, selian itu, faktor keterlibatan dalam organsiasi mendorong perempuan untuk terlibat dalam kegiatan poliik yang lebih konkrit dalam hal ini mencalonkan diri sebagai calon kepala desa sebagaimana yang dialami oleh responden dari desa leuwigede. Masih dieprlukan banyak dukungan dari berbagai pihak melalui berbagai kegiatan dan program sehingga keterlibatan perempuan dalam kegiatan politik meningkat baik dari segi kualitas maupun kuantitas.[]

\section{Daftar Pustaka}

Anderson, L margaret., Thingking About Women Sociological and Feminist Perspectives, New York Macmillan Publishing Co.,Inc., 1983.

Arikunto, Suharsimi. Manajemen Penelitian, Jakarta: Rineke Cipta, 2009. 
Budiarjo, Meriam. Partisipasi dan partai Politik sebuah Bunga Rampai, Jakarta: Gramedia, 1981.

Huntington, Samuel \& Nelson, Joan. Partisipasi Politik di Negara Berkembang, Jakarta: Rineke Cipta, 1994.

Ihsan, Fuad. Dasar-Dasar Kependidikan, Jakarta: PT Rineka Cipta, 2013.

Margono. Metodologi Penelitian Pendidikan, Jakarta: Rineke Cipta, 2010.

Mosse, Cleves Julia. Gender dan Pembangunan, Yogyakarta: Pustaka Pelajar, 2007.

Mulia, Musda. Menuju Kemandirian Politik Perempuan, Yogyakara: Kibar Press, 2008.

Sudjana, Nana \& Ibrahim. Penelitian dan Penilaian Pendidikan, Bandung: Sinar Baru Algensindo, 2012.

Sugihastuti, \& Septiawan, Hadi Itsna. Gender \& Inferioritas Perempuan, Yogyakarta: Pustaka Pelajar, 2010.

Perundang-Undangan

UUD NKRI 1945

UU No. 20 Tahun 2003 Tentang Sistem Pendidikan Nasional

UU No. 39 Tahun 1999 Tentang Hak Asasi Manusia 